\title{
DETERMINATION OF SOME PHYSICAL AND MECHANICAL PROPERTIES OF SUMMER SQUASH (Cucurbita pepo) RELATED TO POST-HARVEST PROCESSES
}

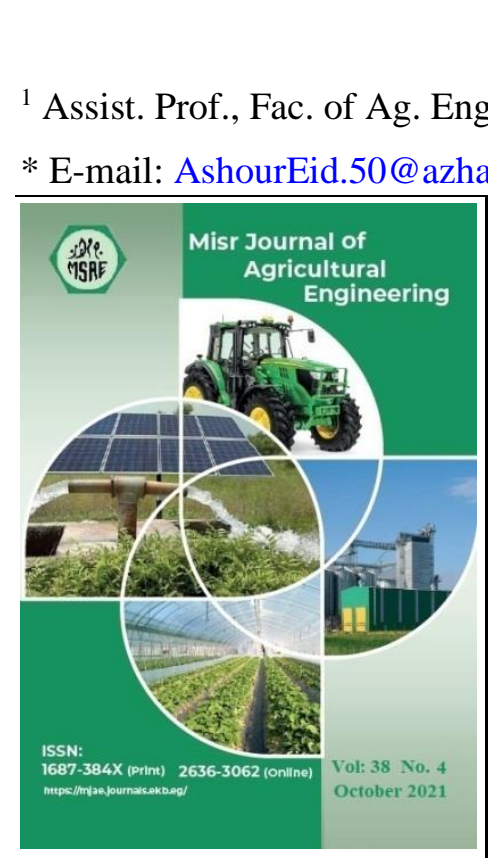

(C) Misr J. Ag. Eng. (MJAE)

* E-mail: AshourEid.50@azhar.edu.eg

\section{Ashour E. Abu El-maaty $1 \& *$}

Assist. Prof., Fac. of Ag. Eng., Al-Azhar U., Assiut Branch, Egypt.

ABSTRACT

The present work aims to study some physical and mechanical properties of squash fruit (Cucurbita pepo), to serve as a database to be used in the design and development of machines used in postharvest processes such as extraction machines for squash fruit. The main results in this study can be summarized as follows: The average fruit length and diameter were 238.72 and $92.17 \mathrm{~mm}$ respectively. The average volume. was 819.26 $\mathrm{cm}^{3}$. The average mass was $614.34 \mathrm{~g}$. The fruit's real density of the sample ranged between 0.72 and $1.3 \mathrm{~g} / \mathrm{cm}^{3}$ (average 0.8 $\left.\mathrm{g} / \mathrm{cm}^{3}\right)$. The fruit projected area of the sample ranges between 187.53 and $257.5 \mathrm{~cm}^{2}$ (average $219.97 \mathrm{~cm}^{2}$ ). The maximum friction angle of 30 degree and the rolling angle of 27 degree were obtained with the wood surface. Whereas, the minimum friction and rolling angles of 19 and 13 degree respectively, were obtained with aluminum surface. The maximum and minimum penetration forces were 48.88 and $44.5 \mathrm{~N}$, respectively. The firmness distribution along the squash surface at 10 and $5 \mathrm{~mm}$ from the top of the fruit were 115.68 and $105.33 \mathrm{~N} / \mathrm{cm}^{2}$, respectively. The maximum, minimum and average axial cutting forces of squash fruits were 68, 35 and $43.75 N$, respectively. The data obtained were subjected to descriptive statistics such as range (maximum "Max" and minimum "Min”), mean, standard deviation (SD), coefficient of variation $(C V)$, frequency distribution, and coefficient of correlation by using a spreadsheet software program (Microsoft Excel 365).

\section{INTRODUCTION}

$\mathrm{S}$ quash belongs to the family (Cucurbitaceae), Scientific Name: (Cucurbita pepo). It is the most important crop in the vegetable crops of the cucurbit family, and it is a summer crop of general cultivation. Squash is rich in carbohydrates, amino acids, and mineral salts that benefit human health. The cultivated area of Squash is 55088 feddan in 2018 and the annual production is about 427346 tons in 2018, (MoA, 2018). It is cultivated throughout the year in the winter, summer, and indigo lugs. Squash contains many important nutrients, including vitamins and minerals, that have many health benefits, including 
improving eyesight, skincare, strengthening the immune system, preventing cancer. Squash is an important source of many nutrients, such as vitamin $\mathrm{C}$, magnesium, and other antioxidant compounds. These vitamins and minerals help prevent cancer, heart disease, and premature aging. In addition, Squash contains high levels of vitamin A, which helps boost the immune system. Many authors (Akubuo and Odigboh, 1999), (Abou-Elmagd, et al., 2002), (Awady et al., 2004), (El Sayed et al., 2009), and (Yehia et al., 2009) referenced that the information on the physical and mechanical qualities of farming items is significant in the plan, of horticultural machines and sorts of hardware. They examined the actual properties and qualities of some rural harvests and natural products, which can be utilized in the plan and improvement of gear.

(Ghanbarian et al., 2008) found that the average mass of the cantaloupe fruits was 697 and $1272 \mathrm{~g}$, the fruit volume was 1084 and $1409 \mathrm{~cm}^{3}$, and the geometric average diameter was 11.7 and $13.12 \mathrm{~cm}$ for Samsouri and shahabadi varieties respectively. (Rashidi and Seyfi, 2007) studied the mass of the melon organic product (Samsouri variety) goes from around 510 to $3380 \mathrm{~g}$, the natural product volume from 538 to $3654 \mathrm{~cm} 3$ and the length from 95 to $185 \mathrm{~cm}$, Major breadth from 106 to $205 \mathrm{~cm}$, Minor width from 101 to $190 \mathrm{~cm}$ and density from 0.78 to $1.07 \mathrm{~g} / \mathrm{cm}^{3}$. (Abd-Alla, 1993) said that the cucumber natural products assortment Beta-alpha properties were: organic product length of 20 and $26 \mathrm{~cm}$, organic product breadth of 5 and $6.5 \mathrm{~cm}$, organic product mass of 500 and $650 \mathrm{~g}$, and seed number per natural product of 200 and 600. (Yehia et al., 2011) studied some physical and mechanical properties of the cucumber fruits variety "Beta-alpha" and designed a seed extractor and he said that It is presumed that the actual properties of cucumber natural products were: width of 52.15 and $229.5 \mathrm{~mm}$, length of 52.15 and $68.87 \mathrm{~mm}$, the mass of 273.8 and $470.4 \mathrm{~g}$, the volume of 380 and $860 \mathrm{~cm}^{3}$, the projected area of 250 and $500 \mathrm{~cm}^{2}$, a real density of 0.94 and $1.10 \mathrm{~g} / \mathrm{cm}^{3}$, bulk density of $0.41 \mathrm{~g} / \mathrm{cm}^{3}$, and sphericity of 3.13 and 3.77 , and mechanical properties are: cucumber-fruit firmness $=64-100.9 \mathrm{~N} / \mathrm{cm}^{2}$, the axial cutting force of 30 and $70 \mathrm{~N}$. (Abu ElMaaty, 2016) used the physical and mechanical properties were used in the design of the cucumber-seed extractor such as feeding mechanism, fruit edge-cutting knives, seedextraction mechanism, pressing mechanism, and two-wings ejector. The assurance of the physical, mechanical, and streamlined properties of quinoa seeds like those different seeds are helpful for further developing the innovation related with the various tasks and hardware identified with the postharvest cycle (Gallagher et al., 2004). The target of this examination was to research the physical, mechanical, and streamlined properties of the quinoa seeds that influence the plan and advancement of the postharvest cycle (Kachru et al., 1994).

The present research aims to study some of the physical and mechanical properties of squash fruit (Cucurbita pepo) to serve as a database to be used in the design and development of machines used in postharvest processes such as extraction machines for squash fruit.

\section{MATERIAL AND METHODS}

\section{1. Fruits.}

The squash fruit in this study belongs to the family (Cucurbitaceae), Scientific Name: (Cucurbita pepo) is a variety (New Eskandarani H1). This study was considered completed by using a random example of 100 natural products in April 2020 season. The plants of squash 
trees were randomly sampled (the farm in Shandawil Research Station, Sohag Governorate, during this period, echoes of the disease), and this was an indication at the same time.

\section{2. Physical properties of Squash fruits.}

The physical properties were mass, volume, dimensions, geometric mean diameter, bulk and real density, shape and size, projected area, surface area, sphericity, arithmetic mean diameter and moisture content were determined for squash.

\section{Dimensions of squash fruits:}

The measured dimensions of squash fruits were fruit length (L), diameter (d) and thickness (c) of 100 fruits. Geometric mean diameter $\left(D_{g}\right)$, arithmetic means diameter $\left(D_{a}\right)$ and sphericity $(\varphi)$ values were found using the following equation (Mohsenin, 1986), (Guner and Dursun, 2003).

$$
\begin{aligned}
D_{g} & =(\text { L.d.c })^{\frac{1}{3}} \\
D_{a} & =\frac{L+d+c}{3} \ldots \\
\varphi & =\frac{(\text { L.d.c })^{\frac{1}{3}}}{L}
\end{aligned}
$$

Where: $\mathrm{L}, \mathrm{d}$ and c are length, diameter and thickness respectively.

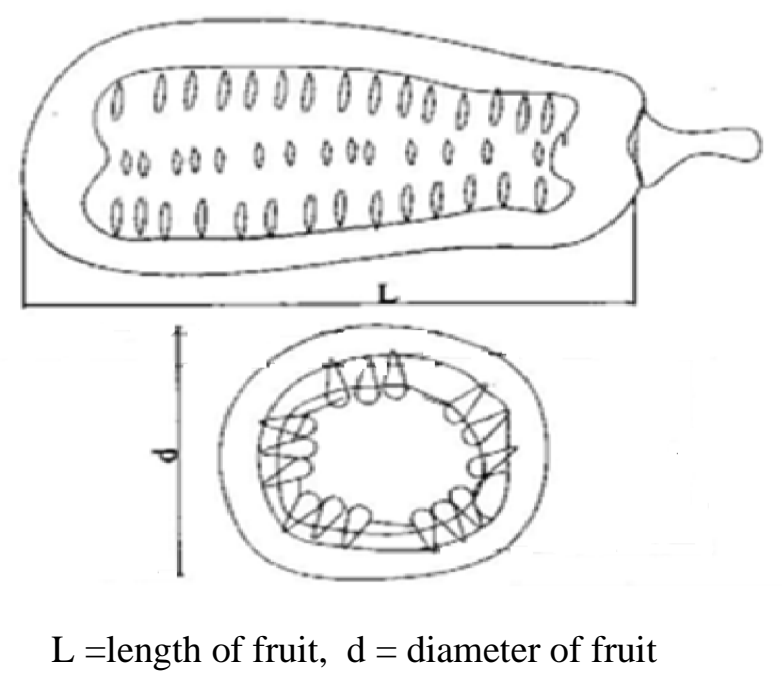

Fig. 1: The sectional view of squash fruit

\section{Shape and size of squash fruit.}

A sample of 100 fruits was used to measure the diameter (d), length (L) and thickness of the peels $(\mathrm{m})$ of each fruit. The obtained data were used to measure the shape index of each sample $\left(L_{s h}\right)$ according to (Buyanov and Voronyuk, 1985).

$$
L_{s h}=\frac{L}{d}
$$

\section{where:}

$L_{s h}$ - Shape index.

$L$ - Length of fruit.

$d$ - Med diameter of the fruit. 


\section{The surface and Projected area of squash fruit.}

The surface area of Squash was found by analogy with a sphere of the same geometric mean diameter, using expression cited by (Olajide and Ade-Omowaye, 1999), (Rashid and

Lorestani and Jaliliantabar, 2012).

$$
S=\pi\left(D_{g}\right)^{2}
$$

\section{Projected area $=(\mathrm{d} * \mathrm{~L})$}

\section{The moisture content of squash fruit.}

The moisture content was determined by using standard methods (ASAE, 2002). The initial moisture content of the samples was determined by oven drying at $104^{\circ} \mathrm{C}$ for $24 \mathrm{~h}$ and calculated by the following equation.

$$
M_{c}=\frac{m_{b}-m_{a}}{m_{a}} \times 100
$$

where: $M_{c}$ is moisture content; $m_{a}$ and $m_{b}$ are masses of samples before and after putting them in the oven, respectively.

\section{The Mass of squash fruit}

Mass of squash fruits was measured in $\mathrm{kg}$, the average mass was calculated from a sample of 100 fruits. The balance has a range between 0.00 to $10.00 \mathrm{~kg}$, and its sensitive to $100 \mathrm{~g}$.

\section{The volume of squash fruits}

The volume of samples was measured in $\mathrm{cm}^{3}$, the average volume was determined by the water displacement method. several samples were weighed and each one was dropped, separately into a $2000 \mathrm{~mL}$ with an accuracy of $25 \mathrm{~mL}$ measuring cylinder filled with distilled water up to $500 \mathrm{ml}$. The rise in water indicated the true volume of the Squash. From the mass and the true volume of the Squash, the real density was calculated. For each case, the determination was replicated many times and the mean was considered.

\section{Real and bulk density of squash fruit}

The volume of each fruit was measured by using a container $23 \times 23 \times 35 \mathrm{~cm}$, the container was filled with water to max level. Then the fruit completely immersed in the container. The flooded water collected in a trough and measured by using beaker of 1-liter capacity. The fruit volume was calculated by using the difference between the two measured volumes of water for each fruit. The displacement, which equals the volume of fruit was calculated in addition the density. The bulk density is calculated. The real density was calculated from the mass and the true volume of the squash.

The mean of density of fruits was calculated as follow:

$$
\rho=\frac{M}{V} \text {. }
$$

where:

$\rho=$ The density of the individual fruit, $\mathrm{g} / \mathrm{cm}^{3}$

$M=$ Mass of the individual fruit, $\mathrm{g}$

$V=$ the volume of individual fruit, $\mathrm{cm}^{3}$ 


\section{3. Mechanical properties of Squash fruits}

The Mechanical properties in this research included that the rolling angle, Coefficient of static friction, Penetration force, firmness and cutting force of Squash fruits.

\section{Rolling angle}

The fruits are placed on a horizontal surface one by one then the angle of inclination is gradually increased until the fruits begin the roll. For each fruit of an average 50 samples, two angles of rolling are determined: for the maximum stable with their base down and minimum stable positions (Buyanov and Voronyuk, 1985)

\section{Coefficient of static friction}

The fruits are placed as a group bonded together on a horizontal surface then the angle of inclination is gradually increased until the fruits begin sliding without rolling. For each fruits group of an average ten samples, the friction angles were determined, (Oje and Ugbor, 1991).

\section{Penetration force}

A penetrometer, made in Italy, with an accuracy of $0.1 \mathrm{~N}$ was used to measure the penetration force of squash fruits. The firmness of the fruit was obtained by dividing the penetration force by the area of $0.28 \mathrm{~cm}^{2}$ of the cylindrical probe, which had $0.6 \mathrm{~cm}$ in diameter.

\section{4. Instrumentation:}

Digital caliper with vernier: with an accuracy of $0.01 \mathrm{~mm}$, to measure different dimensions of Squash fruits.

Digital balance: with an accuracy of $0.2 \mathrm{~g}$, to measure the mass of Squash fruits.

Graduated cylinder: of $2000 \mathrm{~mL}$ with an accuracy of $25 \mathrm{~mL}$ to determine the real density and volume of fruit by immersion in water.

\section{6. Statistical analysis.}

The data obtained were subjected to descriptive statistics such as range (maximum "Max" and minimum "Min"), mean, standard deviation (SD), coefficient of variation (CV), frequency distribution, and coefficient of correlation by using a spreadsheet software program (Microsoft Excel 365).

\section{RESULTS AND DISCUSSION}

Table 1 shows dimensions, sphericity, mass, volume, real density, projected area, pulp thickness and mass and seed number and mass per fruit of squash fruits. These data were measured on 100 fruit samples, according to the standards set by (Mohsenin, 1986).

\subsection{Physical properties:}

As is shown in Table 1 the dimensions (Length, Diameter and thickness) of Squash vary in the ranges of $214-261 \mathrm{~mm}, 79.8-103 \mathrm{~mm}$ and $79-102 \mathrm{~mm}$, respectively. The arithmetic means diameters and geometric mean diameters of Squash were $124.27-155.33 \mathrm{~mm}$ and $110.5-139.9 \mathrm{~mm}$, respectively. The volumes and unit masses of Squash were from 659 to $998 \mathrm{~cm}^{3}$ and from 528.6 to $896 \mathrm{~g}$. The projected area was from 187.53 to $257.5 \mathrm{~cm}^{2}$. (Bal and 
Mishra, 1988), and (Dutta, Nema and Bhardwaj, 1988) considered the grain as spherical when the sphericity value was more than 0.80and 0.70, respectively. In this study, Squash should not be treated as an equivalent sphere for calculation of the surface area, because the sphericity of Squash was between $2.21 \%-3.14 \%$. The ranges of moisture and density are from $93.1 \%-96.7 \%$ and $0.72-1.3 \mathrm{~g} / \mathrm{cm}^{3}$ respectively, too.

\section{The principal dimensions.}

Figure 2 and table 1 show the averages of the dimensions of one hundred fruits. Standard deviation and coefficient of variation as shown in table 1 . The measurements of length $\mathrm{L}$, diameter $\mathrm{D}$. The highest value of fruit length and diameter were 261- $103 \mathrm{~mm}$ respectively, while the lowest value of fruit length and diameter were $214-79.8 \mathrm{~mm}$, respectively. The highest frequencies of fruit length and diameter were 20 and $25 \%$ at $(235-240 \mathrm{~mm})$, (85$90 \mathrm{~mm}$ ) respectively.

Table 1: Physical properties of Squash fruits.

\begin{tabular}{|c|c|c|c|c|c|}
\hline The Physical properties & Max. & Min. & Ave. & S.D & C.V \% \\
\hline Length, mm. & 261 & 214 & 238.72 & 12.79 & 5.35 \\
\hline Diameter, mm. & 103 & 79.8 & 92.17 & 5.18 & 5.62 \\
\hline thickness, mm. & 102 & 79 & 91.9 & 5.01 & 5.45 \\
\hline Sphericity, \%. & 3.14 & 2.21 & 2.60 & 0.21 & 8.23 \\
\hline The projected area, $\mathrm{cm}^{2}$. & 257.5 & 187.53 & 219.97 & 16.6 & 7.55 \\
\hline Fruit mass, g. & 896 & 528.6 & 641.34 & 102.55 & 15.99 \\
\hline Fruit volume, $\mathrm{cm}^{3}$. & 998 & 659 & 819.26 & 123.44 & 15.07 \\
\hline Bulk density, $\mathrm{g} / \mathrm{cm}^{3}$ & \multicolumn{5}{|c|}{0.49} \\
\hline Real density, $\mathrm{g} / \mathrm{cm}^{3}$ & 1.3 & 0.72 & 0.8 & 0.16 & 19.54 \\
\hline Geometric mean diameter, mm. & 139.9 & 110.5 & 121.45 & 8.46 & 3.54 \\
\hline Arithmetic means diameter, $\mathbf{m m}$. & 155.33 & 124.27 & 136.93 & 11.91 & 8.52 \\
\hline Moisture, \%. & 96.7 & 93.1 & 94.45 & 1.27 & 1.46 \\
\hline Pulp thickness, mm. & 12 & 8 & 9.75 & 1.28 & 13.15 \\
\hline Pulp mass, g. & 733 & 512.4 & 590.7 & 81.31 & 13.77 \\
\hline Seed mass, g. & 40.4 & 16.2 & 28.64 & 8.06 & 28.14 \\
\hline
\end{tabular}

(1) S. D. is the standard deviation.

(2) C. V. is the coefficient of variation.
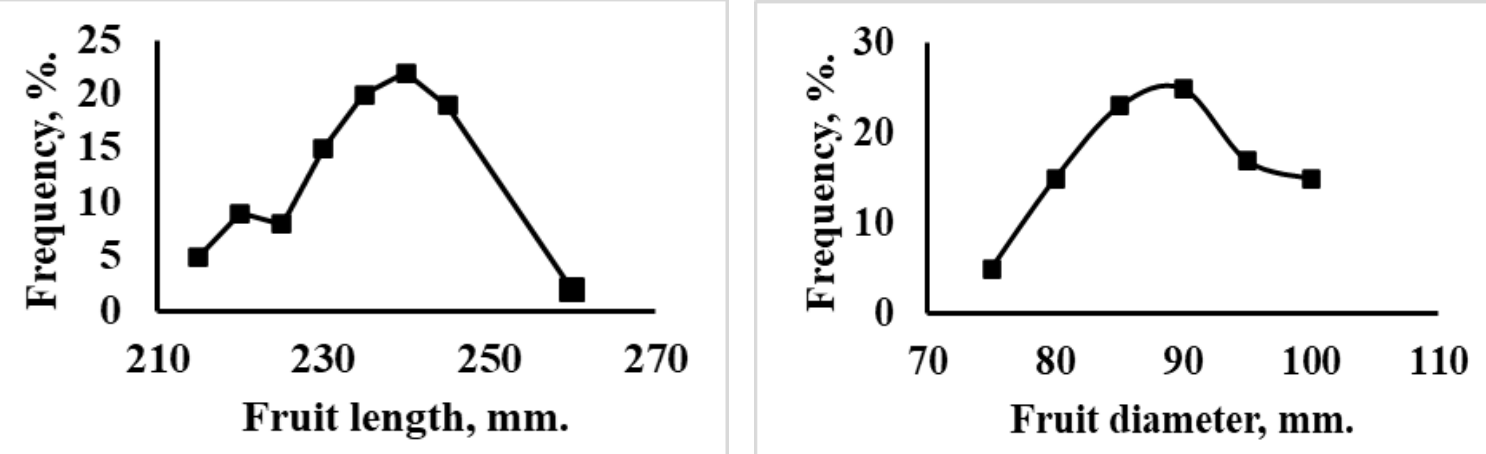

Fig. 2: Frequency curves distribution of fruit diameter and length of squash fruits 


\section{Shape and size of fruit:}

If sphericity is less than 0.9 , the fruit belongs to the oblate group; if sphericity is greater than 1.1 , it belongs to the oblong group. The remaining fruits with intermediate index values are considered to be round (Buyanov and Voronyuk, 1985).

Figure 3 indicates that the fruit sphericity ranged in the sample between 2.21 and $3.14 \%$. The most frequent percent $(100 \%)$ squash fruits in the sample were oblong (sphericity $2.21-3.14$ $\%)$.

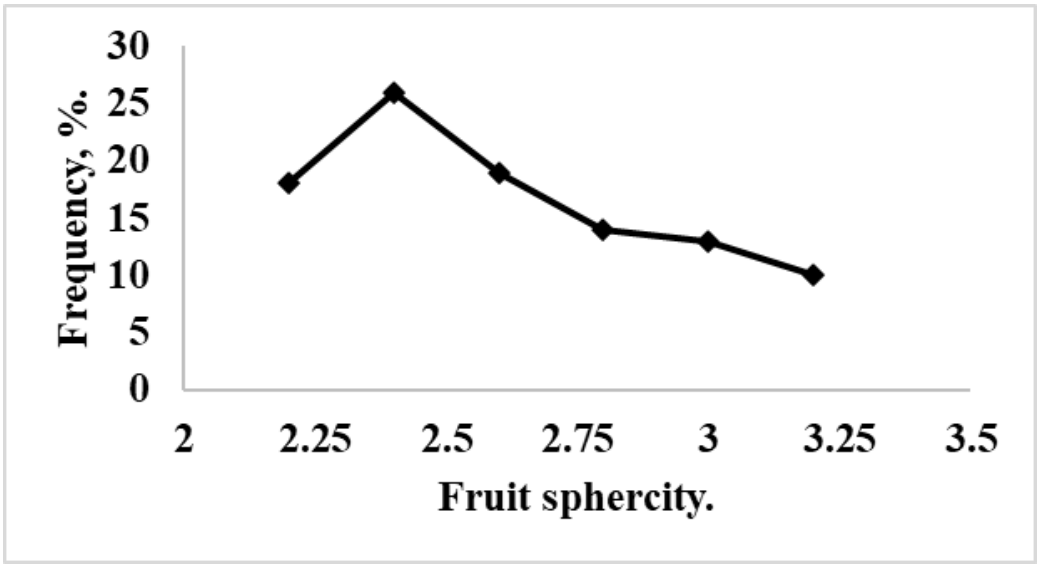

Fig. 3: Frequency curves distribution of fruit sphericity of squash fruits

\section{The volume of squash fruits}

Figure 4 indicates that the volume of Cucurbita pepo fruits was measured in $\mathrm{cm}^{3}$, which averages the volume of one hundred fruits. Standard deviation and coefficient of variation as shown in table 1. The measurements of the volume. The highest value of fruit volume was $998 \mathrm{~cm}^{3}$, while the lowest value of fruit volume was $659 \mathrm{~cm}^{3}$ respectively.

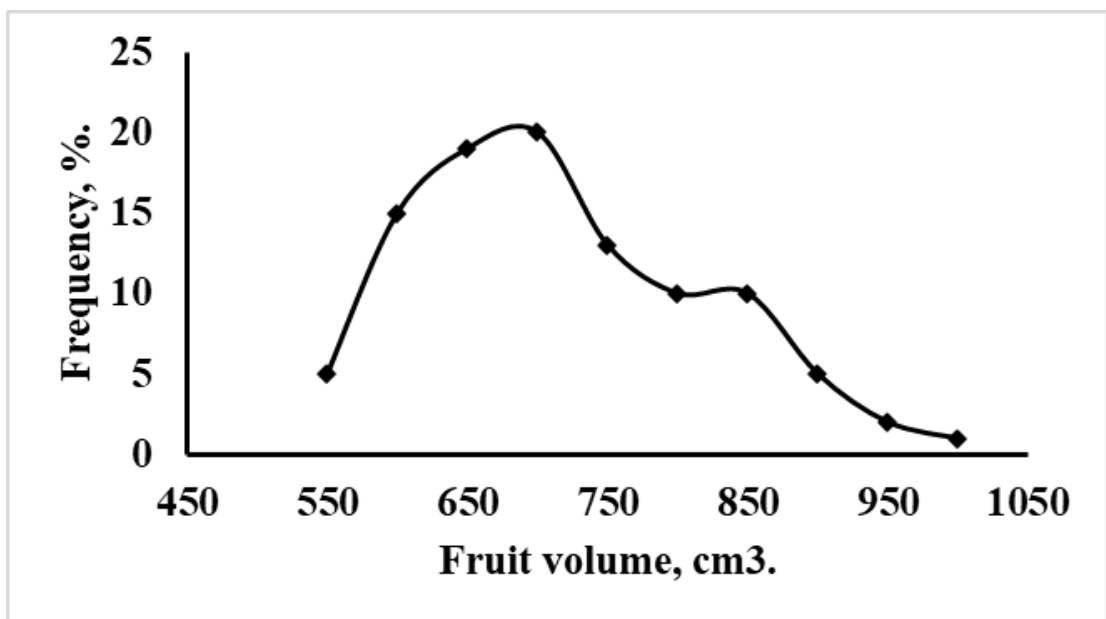

Fig. 4: Frequency curves distribution of fruit volume of squash fruits

\section{The mass of squash fruits.}

Figure 5 indicates that the Mass of Cucurbita pepo fruits was measured in $g$, the average mass was calculated from a sample of (100 fruits). The balance has a range of 0.00 to $10.00 \mathrm{~kg}$, (sensitive to 100 grams). Averages mass of one hundred fruits. Standard deviation and coefficient of variation are shown in table 1. The measurements of the mass. The highest 
value of fruit mass was $896 \mathrm{~cm}^{3}$, while the lowest value of fruit mass was $528.6 \mathrm{~cm}^{3}$ respectively.

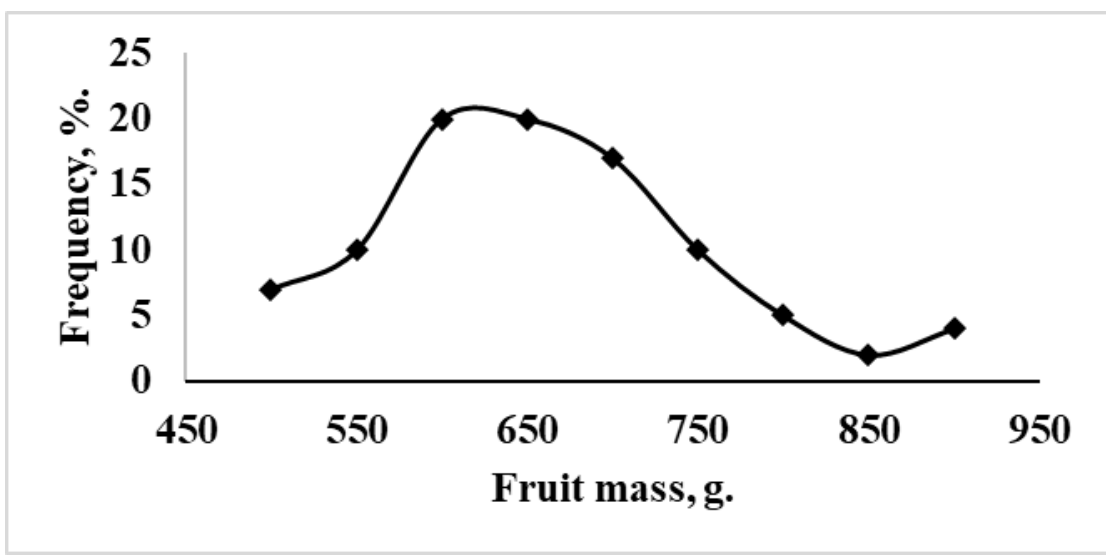

Fig. 5: Frequency curves distribution of fruit mass of squash fruits

From Table 1, the values of arithmetic mean diameter $\left(D_{a}\right)$ ranged from 124.27 to $155.33 \mathrm{~mm}$ with a mean value of $136.93 \mathrm{~mm}$. Meanwhile, the values of the geometric mean diameter $\left(D_{g}\right)$ ranged from 110.5 to $139.9 \mathrm{~mm}$ with a mean value of $121.45 \mathrm{~mm}$. Fig. (6) shows the relationship between the arithmetic and geometric mean diameter of squash fruit.

This relationship indicates that the average diameters calculated by the arithmetic and the geometric mean methods were almost the same and the coefficient of correlation is very high and closer to $1\left(R^{2}=0.9058\right)$. So, the correlation between $D_{a}$ and $D_{g}$ is a positive strong correlation as shown in Fig. (6). Therefore, either the arithmetic mean or the geometric mean method can be used to calculate the equivalent diameter of Squash fruit.

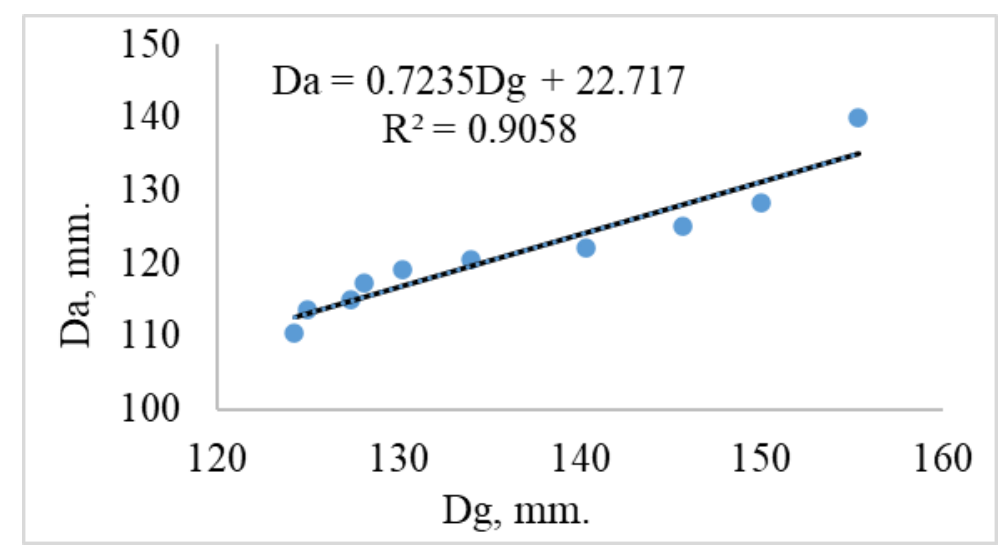

Fig. 6: Arithmetic versus geometric mean diameter of squash fruits

\section{The real density of fruit:}

Figure 7 and table 1 indicate that the fruit real density of the sample ranged between 0.72 and $1.3 \mathrm{~g} / \mathrm{cm} 3$ (average $0.8 \mathrm{~g} / \mathrm{cm}^{3}$ ). The most frequent percent $(75 \%)$ of squash fruits in the sample had $0.85-0.95 \mathrm{~g} / \mathrm{cm} 3$ real density.

\section{The projected area of fruit.}

Figure 8 and table 1 indicate that the fruit projected area of the sample ranges between 187.53 and $257.5 \mathrm{~cm}^{2}$ (average $219.97 \mathrm{~cm}^{2}$ ). The most frequent percent $(75 \%)$ of squash fruits in the sample have $200-220 \mathrm{~cm}^{2}$ projected area. 


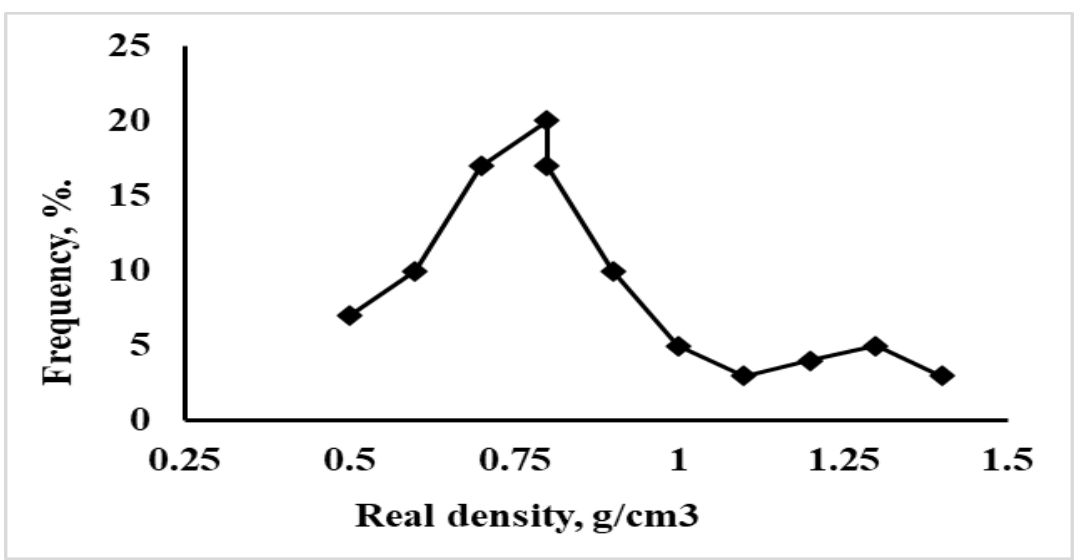

Fig. 7: Frequency curves distribution of fruit real density of Squash fruits

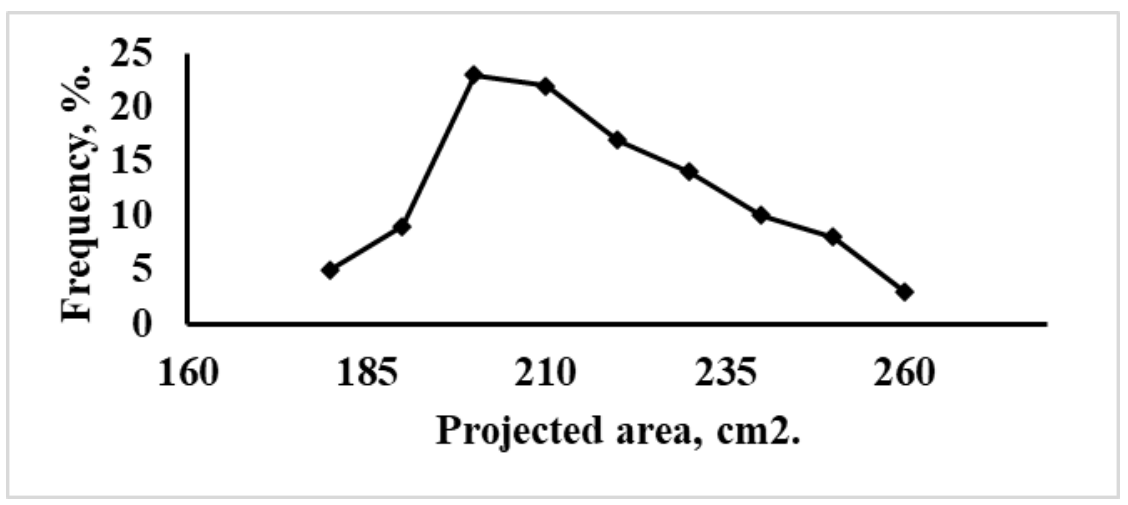

Fig. 8: Frequency curves distribution of projected area of Squash fruits

\section{Pulp thickness and mass.}

Figure 9 indicates that the pulp thickness and mass ranges of the sample were $8-12 \mathrm{~mm}$ (average $9.75 \mathrm{~mm}$ ) and $512.4-733.1 \mathrm{~g}$ (average $590.74 \mathrm{~g}$ ), respectively. The most frequent percent $(87.5 \%)$ of squash fruits in the sample have $10-11 \mathrm{~mm}$ thickness and $(87.5 \%)$ have 650 - 700 g mass.

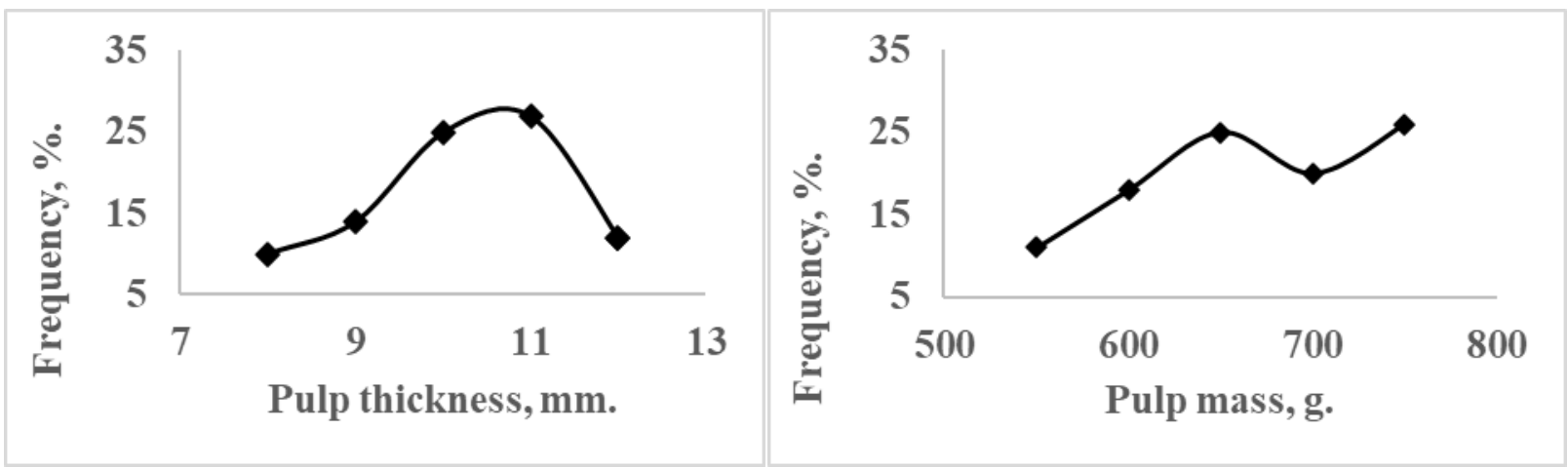

Fig. 9: Frequency curves distribution of pulp thickness and pulp mass of Squash fruits

\subsection{Mechanical properties of squash fruits.}

\section{Friction and rolling angles of squash fruits.}

Table 2, Figure 10 and 11 shows the friction and rolling angles of squash fruits. The maximum friction angle 30 degree and rolling angle 27 degree were obtained with the wood surface. Whereas, the minimum of friction and rolling angles 19 and 13 degree, respectively, were obtained with aluminum surface. 


\section{Penetration force and firmness of squash fruits.}

Table 3 and Figure 12 show the penetration force and firmness distribution averages along squash surface: the maximum of $48.88 \mathrm{~N}$ and $115.68 \mathrm{~N} / \mathrm{cm}^{2}$ at $10 \mathrm{~mm}$ from top of the fruit, the minimum of $44.5 \mathrm{~N} 105.33 \mathrm{~N} / \mathrm{cm}^{2}$ at $5 \mathrm{~mm}$ from top of the fruit respectively.

\section{Cutting force of squash fruits.}

Table 2 and Figure 12 shows the axial cutting forces of squash fruits were: the maximum 68 $\mathrm{N}$, the minimum $35 \mathrm{~N}$, and the average $43.75 \mathrm{~N}$.

Table 2: Penetration force, Firmness, and cutting force of squash fruits.

\begin{tabular}{|c|c|c|c|c|c|c|}
\hline Mechanical properties & $\mathrm{L}, \mathrm{cm}^{(1)}$ & Min. & Max. & Av. & S. D. ${ }^{(2)}$ & C. V. $^{(3)}$ \\
\hline \multirow{3}{*}{ Penetration force, N } & 5 & 32 & 63 & 44.5 & 9.58 & 21.52 \\
\cline { 2 - 7 } & 10 & 33 & 85 & 48.88 & 15.63 & 31.99 \\
\cline { 2 - 7 } & 15 & 33 & 75 & 47.88 & 12.08 & 25.22 \\
\hline \multirow{3}{*}{ Firmness, N/cm } & 2 \\
\cline { 2 - 7 } & 5 & 75.7 & 149 & 105.33 & 22.67 & 21.52 \\
\cline { 2 - 7 } & 10 & 78 & 201 & 115.68 & 37 & 31.99 \\
\hline Cutting force, N & Axial & 35 & 68 & 43.75 & 11.09 & 25.35 \\
\hline
\end{tabular}

(1) $\mathrm{L}$ is the distance from the top of the fruit.

(1) S. D. is the standard deviation.

(2) C. V. is the coefficient of variation.

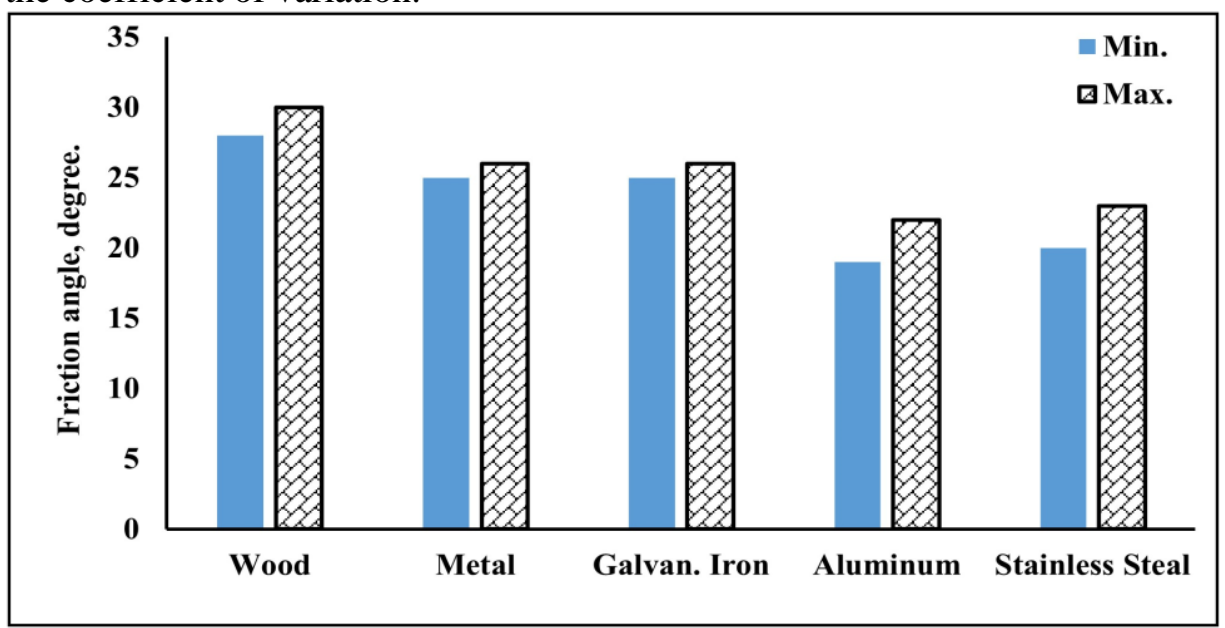

Fig. 10: The friction angle of squash fruits.

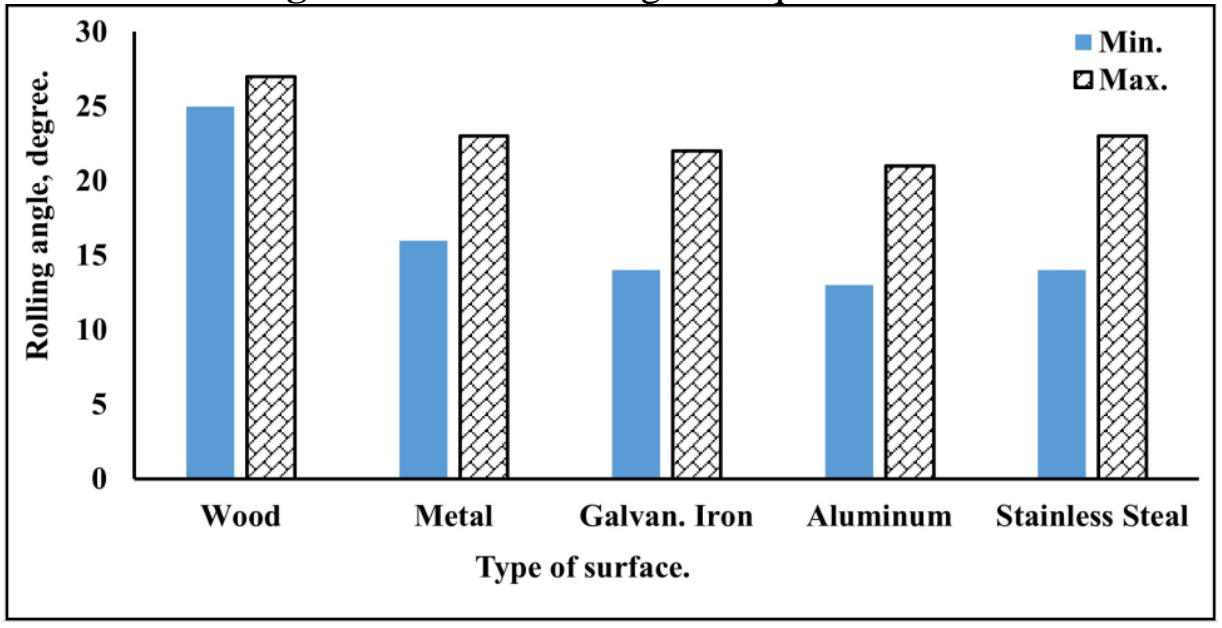

Fig. 11: The rolling angle of squash fruits. 


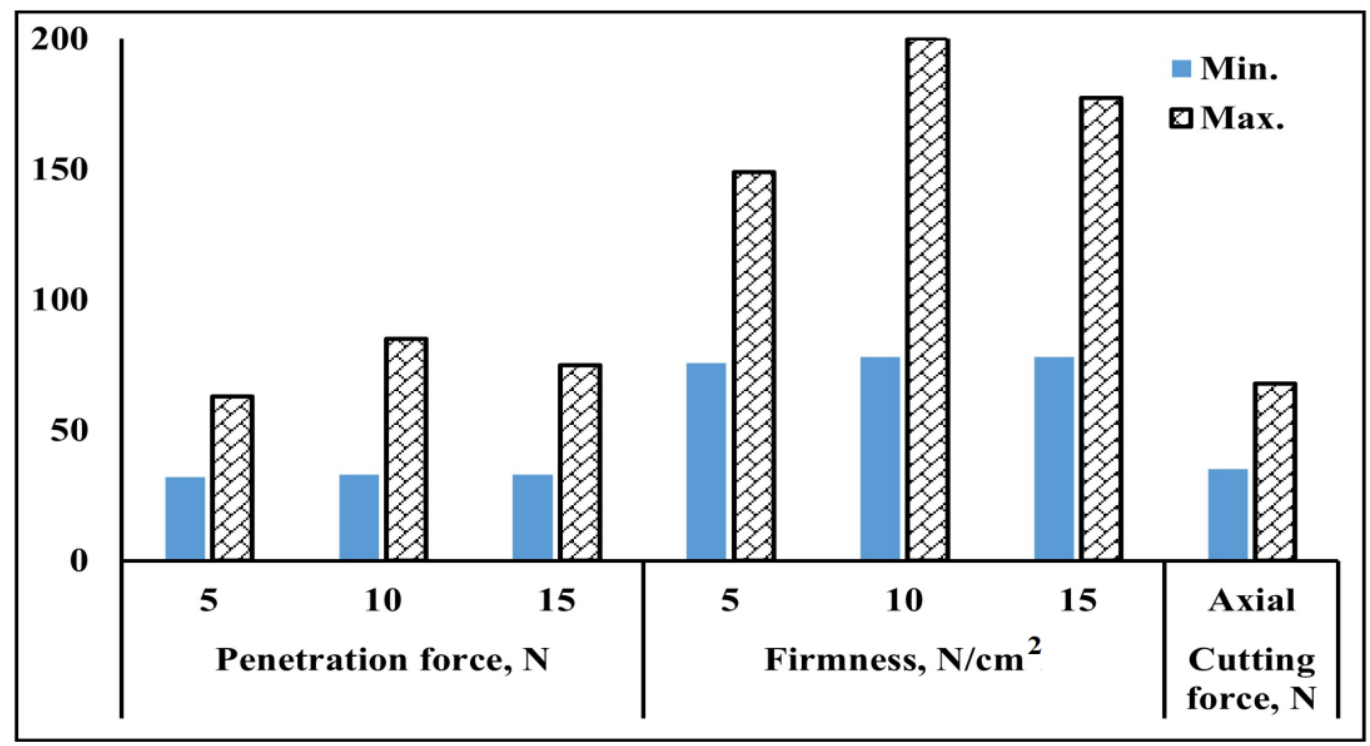

Fig. 12: The penetration force, firmness, and cutting force distribution averages along the squash surface.

\section{CONCLUSION}

The main results in this study can be summarized as follows:

1 - The highest value of fruit length and diameter were 261 and $103 \mathrm{~mm}$ respectively, while the lowest value of fruit length and diameter were 214 and $79.8 \mathrm{~mm}$ respectively.

2- The measurements of the volume. The highest value of fruit volume was $998 \mathrm{~cm}^{3}$, while the lowest value of fruit volume was $659 \mathrm{~cm}^{3}$.

3- The measurements of the mass. The highest value of fruit mass was $896 \mathrm{~cm}^{3}$, while the lowest value of fruit mass was $528.6 \mathrm{~cm}^{3}$.

4- The fruit's real density of the sample ranged between 0.72 and $1.3 \mathrm{~g} / \mathrm{cm}^{3}$ (average 0.8 $\mathrm{g} / \mathrm{cm}^{3}$ ). The most frequent percent $75 \%$ of squash fruits in the sample had 0.85 and 0.95 $\mathrm{g} / \mathrm{cm}^{3}$ real density.

5- The fruit projected area of the sample ranges between 187.53 and $257.5 \mathrm{~cm}^{2}$ (average $219.97 \mathrm{~cm} 2$ ). The most frequent percent $75 \%$ of squash fruits in the sample have 200 and $220 \mathrm{~cm}^{2}$ projected area.

6- The maximum friction angle 30 degree and rolling angle ranges 27 degree were obtained with the wood surface. Whereas, the minimum ranges of friction and rolling angles 19 and 13 degree respectively were obtained with aluminum surface.

7- The penetration force and firmness distribution averages along the squash surface: the maximum $48.88 \mathrm{~N}$ and $115.68 \mathrm{~N} / \mathrm{cm}^{2}$ at $10 \mathrm{~mm}$ from top of the fruit, the minimum $44.5 \mathrm{~N}$ $105.33 \mathrm{~N} / \mathrm{cm}^{2}$ at $5 \mathrm{~mm}$ from top of the fruit respectively.

8- The axial cutting forces of squash fruits were: the maximum $68 \mathrm{~N}$, the minimum $35 \mathrm{~N}$, and the average $43.75 \mathrm{~N}$. 


\section{REFERENCES}

Abd-Alla, A. M. (1993) 'Physiological studies on the yield and quality of cucumber seeds' Ph. D., Hort. Dept., Ag. Col., Ain Shams U.: 67-68.

Abou-Elmagd, A.E.; Hamam, A. S.; EL-Saadany, M. A. and S. A. El-Kawaga. (2002). Design of a cone-end detacher for orange picking, Misr. J. Ag. Eng. 19(2): 491-507.

Abu-El Maaty, A. E. (2016) Development a seed-extraction machine for cucumber fruits, Ph. D., Fac. of Ag., Banha Univ., Moshtouhor: 31 - 103.

Akubuo, C.O. and E. U. Odigboh. (1999). Egusi fruit coring machine. J. Agric. Engng Res. 74: 121-126.

Awady, M. N., I. Yehia., M. A. Hassan. And A.M. El Lithy. (2004). 'Some physical and mechanical properties of Minneola fruits’ Misr J. Ag. Eng., 21(2): 669-684.

Bal, S., and H. N. Mishra. (1988). Engineering properties of soybean. In: Proceedings of the National Seminar on Soybean Processing and Utilization in India, 146-165.

Buyanov, A. I., and B. A. Voronyuk. (1985) 'Physical and mechanical properties of plants', fertilizers and soils. New Delhi, Bombay, Calcutta, New York: Amerind publishing Co. Pvt. Ltd.

Dutta, S. K., Nema, V. K. and Bhardwaj, R. K. (1988) Physical Properties of Gram. Journal of Agricultural Engineering Research, 39: 259-268.

El Sayed, G. H., S. Harb., I. Yehia. and Arif, E. M. (2009) 'Development of an automatic juicer for minneola fruits', Misr J. Ag. Eng., 34(4): 4155-4167.

Gallagher, E., T. R. Gormley. and E. K. Arendt. (2004) 'Recent advances in the formulation of gluten-free cereal-based products'. Trends in Food Science \& Technology, 15(3-4), 143-152

Guner, M., E. Dursun, and I. G. Dursun. (2003) 'Mechanical Behaviour of Hazelnut under Compression Loading. Biosystems Engineering', 85(4): 485-491.

Kachru, R. P., R. K. Gupta. and A. Alam. (1994) 'Physico-chemical constituents and engineering properties of food crops' Scientific Publishers ISBN: 81-7233-083-9

Ministry of Agriculture. (2018) Agricultural statistics, Economical Issues Sector, Cairo, Egypt: 84-107.

Mohsenin, N. N. (1986) Physical properties of plant and animal materials, Gordon and Breach Sc. Pub., N. Y.

Rashidi, M. and K. Seyfi. (2007) 'Classification of fruit shape in cantaloupe using the analysis of geometrical attributes' World J. of Ag. Sciences, Iran, 3(6): 735-740. 
Rashid G., A. N. Lorestani., F. Jaliliantabar. (2012) 'Determination of physical and mechanical properties of Zucchini (summer squash)' Agric Eng. Int: CIGR Journal Vol. 14, No.1: 136 - 140.

Olajide, J. D., and B. I. O. Ade-Omowaye. (1999) 'Some physical properties of locust bean seed'. Journal of Agric. Eng. Research, 74(2): 213-215.

Yehia, I., M. M. Atallah., K. S. Khalil., A. M. El-Lithy. (2011) 'physical and mechanical properties of cucumber applied to seed extractor' J. Soil Sci. and Agric. Eng., Mansoura Univ., Vol. 2 (8): $871-880$. 
تحديد بعض الخواص الطبيعية والميكاتيكية لثمار الكوسة المتعلقة بعمليات ما بعد الحصاد

د. عاثور عيد أبو المعاطي حسين'

' مدرس - كلية الهندسة الزر اعية - جامعة الأزهر فرع أسيوط ـ مصر.

الملخص العربي مرعي

يهدف هذا البحث إلى دراسة بعض الخواص الطبيعية والميكانيكية لثمار الكوسة في

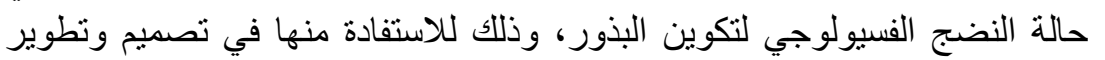

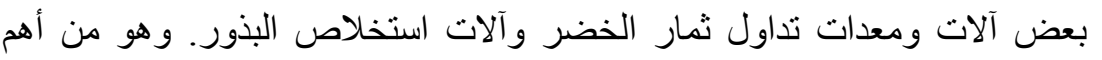

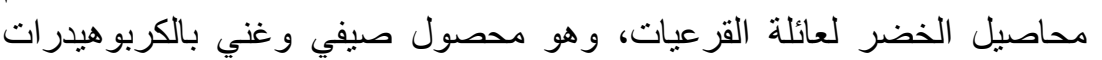

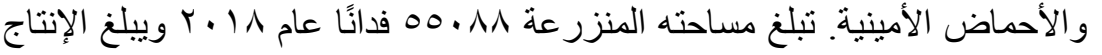

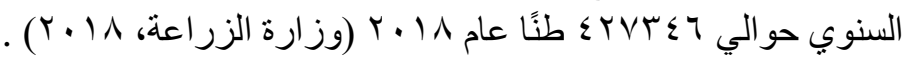
وتم الحصول على النتائج التالية: : (1) (1) الخواص الطبيعية

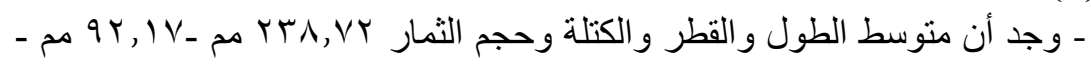

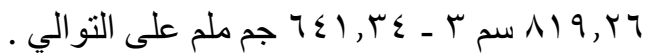

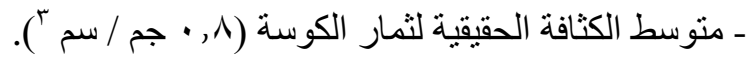

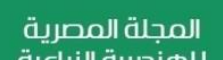

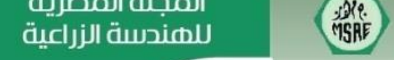

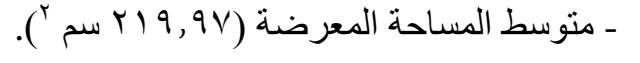

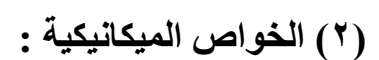

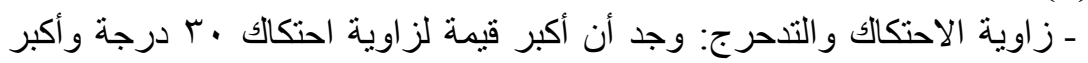

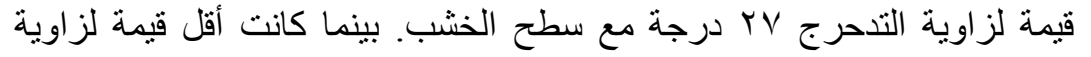

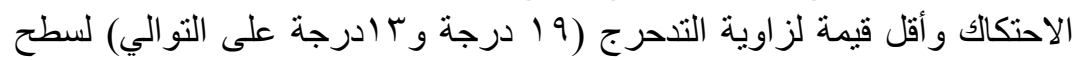
الألمنيوم. - الأناك. ـ قوة الاختر اق و الصلابة: وجد أن منوسط قوة الاختر اق ومتوسط قوة الصلابة على الكى

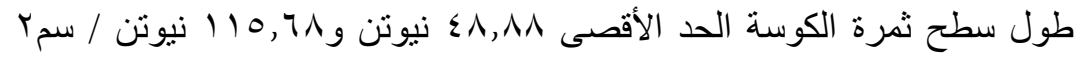

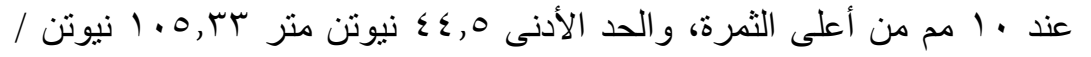

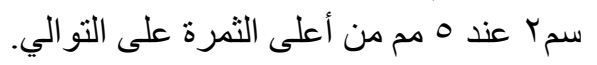

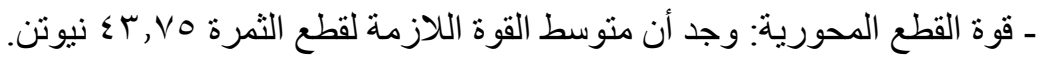

